\title{
A Study on the Improvement of Collective Management System of Copyright in the Digital Era
}

\author{
Chenyi Zhao ${ }^{1 \text { a }}$ \\ ${ }^{1}$ Law school, Shandong University, Jinan, 266237, China \\ a65131889@qq.com

\begin{abstract}
With the development of digital technology and the Internet, large-scale digitization has brought fundamental changes in the way of acquisition, utility and dissemination of works. In order to solve the dilemmas such as unbalanced interests of all parties in the copyright collective management system under the legal monopolistic mode, this paper uses the comparative method to learn from the beneficial experience of collective management system reform in various countries, as well as reform the existing collective management mode of legal monopoly and put forward suggestion on introducing extended management to perfect and optimize the existing collective management system, so as to realize the digitalization of copyright collective management in our country.
\end{abstract}

Keywords: digital technology, copyright collective management system, package licensing, extended collective management

\section{INTRODUCTION}

Due to the development of technologies like recording and broadcasting, copyright trades have become increasingly complicated, and the copyright collective management system, as a kind of licensing mechanism to reduce the cost of centralized rights, has come into being, which solves the dilemma of not being able to license on a large scale and reduces the cost of users when using works. However, faced with the development of social environment and technological conditions in the digital era, problems existing in the collective management system on the aspects such as the balance of interests, the way of authorization and the protection of non-members' rights, etc. are becoming increasingly prominent.

\section{AN OVERVIEW OF COPYRIGHT COLLECTIVE MANAGEMENT SYSTEM}

\subsection{The Connotation and Origin of Copyright Collective Management System}

Copyright Collective Management refers to the activities of collective management organizations of copyright, which, with the authorization of the right holder, centrally exercise relevant rights of the right holder, carry out licensing contracts in their own name, collect transfer fees and royalties, as well as conduct litigation and arbitration of copyright and related rights. Originating in France in 1777, the system is the first copyright collective management organization formed spontaneously by playwrights for purpose of requiring theaters to recognize their copyright. In 1992, China introduced the collective management system of copyright and successively established five copyright collective management organizations, namely Music Copyright Society of China, China Audio-Video Copyright Association, Images Copyright Society of China, China Written Works Copyright Society and China Film Copyright Association.

\subsection{The Significance and Advantages of Copyright Collective Management System}

The copyright collective management system is an inevitable outcome of the development of social economy and culture, which is of a great significance to protect the rights of copyright owners as well as promote the operation of cultural market and development of cultural industry. As far as the subject is concerned, a copyright owner gains a favorable position in the market by means of collective licensing, and interests are protected; users obtain the right to use a large quantity of works at one time through one-stop licensing of 
collective management organizations, reducing both the transaction cost and the risk of infringement.

\section{CURRENT SITUATION AND COMPARATIVE ANALYSIS OF COLLECTIVE MANAGEMENT SYSTEM}

There are several modes in the collective management system of copyright, including the competitive modes led by the United States and the monopolistic modes existed in Germany, Italy and other countries. As a country where copyright collective management system started late, choosing a collective management system that suits the country's national conditions is particularly important for the development of copyright in China

\subsection{Mode of Collective Management System in China}

\subsubsection{Theory}

The traditional collective management modes can be divided into a competitive mode and a monopolistic mode. While the competitive mode emphasizes competitions, the monopolistic mode emphasizes the monopolistic status of collective management organizations, with which the state strictly restricts and regulates the establishment of organizations. In fact, China has chosen a packaged management mode of centralized licensing that excludes competitions and maintains monopolies, preserving the monopolistic status of collective management organizations and recognizing the legitimacy of their exclusive authorization. China's academic circle has disputes over whether to adopt competitive mode or monopolistic one. Some scholars still choose the monopolistic mode, believing it could improve the efficiency of trades and authority of copyright collective management organizations. Some choose the competitive mode, considering that monopolistic mode could easily cause collective management organizations to abuse their dominant market position and harm the interests of both copyright owners and third parties, while the competitive mode will implement the principle of copyright private law autonomy and respect the independent selecting right of copyright owners. And some scholars advocate the collective management mode with limited competitions and reasonable monopolies, that is, while establishing a single collective management organization for certain kinds of works, a comprehensive management organization that can provide comprehensive management services for various kinds of works is also established to achieve a reasonable cross-fusion of competitions and monopolies.

\subsubsection{Legislative Provisions}

Since the revision of Copyright Law in 2001, China has stipulated the copyright collective management system in the form of law. On the basis of Article VIII of the Copyright Law, the Regulations on Copyright Collective Management published soon afterwards has made specific provisions on the establishment, composition, management activities, supervision and administration of copyright collective management organizations, which clearly indicates the legal nature of copyright collective management organizations, namely, non-profit organizations established according to laws for the interest of right holders. At the same time, it also stipulates conditions for the establishment of collective management organizations, requiring that the interests of right holders be represented in the whole country and excluding competitions among other collective management organizations in the field of business from the perspective of the system, meanwhile denies the possibility of the existence of private collective management organizations, allowing an institutional monopolistic status is obtained for copyright collective management of our country.

\subsection{An Investigation of Comparative Law in the Collective Management System of Foreign Countries}

Unlike China, where the collective management system of copyright has been recently introduced, the Collective Management System has a development history of nearly 300 years in some foreign countries, where the legal system is more mature and has a series of handling cases and experience.

\subsubsection{Civil Law System}

Germany is a one of the countries that protects copyright earlier with a higher degree and adopts separate legislation mode for copyright collective management. The Law on Copyright Collective Management, established in Germany, recognizes the de facto monopolistic status of copyright management organizations, and the mandatory collective management mode stipulated in it is featured as the following: firstly, monopoly is dominant, but competitions in special fields are allowed; secondly, the degree of state intervention is relatively high, and there is often supervision of administrative departments of the German Government in specific management activities of collective management organizations.

As early as 1939, Japan promulgated the Copyright Intermediary Business Law, regarding the collective management system of copyright. In 2001, after its abolishment, the Law on the Administration of Copyright and Adjacent Rights was put into effect. Unlike the 
previous Copyright Intermediary Business Law, although the latter still stipulates the monopolistic collective management mode, the authority of competent institutions has been reduced. On the aspect of main body qualification of copyright management business operators, it is no longer an absolutely authorized licensing system, instead, it is transferred to a registration system, and the rules on the royalties have also been changed from the approval system to an announcement system. Overall, the access to Japan's copyright management market has become relatively loose, promoting the efficiency of market transactions.

\subsubsection{Common Law System}

With the United States as the representative of competitive mode of copyright collective management organizations, which regards copyright as a movable property, the copyright collective management organizations were thus established in the form of a limited liability company according to the Company Law or the Competition Law, which are restricted by the Competition Law. And the Government generally does not interfere with the establishment and management of copyright collective management organizations. The Government neither grants monopolistic status to collective management organizations nor has special laws to regulate collective management of copyright. In the United States, there are three copyright collective management organizations in the public performance of music compositions, which compete with each other to prevent the monopolization of any single organization, providing more choices for copyright owners and users. Under the market competition mechanism, all kinds of trading subjects choose the most suitable trading modes through comparisons and games, which promote the efficiency of collective management of copyright.

\section{CHALLENGES FACED BY COLLECTIVE MANAGEMENT SYSTEM IN THE DIGITAL ERA}

As an imported product, the copyright collective management system in China still has the problem of non-compatibility with the country's national conditions, especially under the background of the digital era, where it is difficult for the traditional collective management system to adapt to the large-scale data environment of the Internet, causing a series of new problems.

\subsection{Unbalance of Interests of All Parties under the Legal Monopolistic Mode}

The recognition of the monopolistic status of collective management organizations indirectly provides a possibility for the expansion of their authority, which leads to the unbalance of rights and obligations within those collective management organizations: the first is that a collective management organization is no longer a civil subject with balanced rights and obligations in the real sense; the second is that the monopolistic status of a collective management organization is under the special protection of the laws. Under the situation with only one strong system, collective management organizations often lack motive force for reform and the consciousness of taking the initiative to undertake obligations; the third is the nature of collective management organizations is self-governing, which convene general meetings of members to carry on their self-restraint only through the spontaneous release of the annual reports, so that the transparency of information disclosure is not enough. In the perspective of collective management organizations and copyright owners, with organizations as a strong subject, the right-holders lose the right to choose in many cases. In addition, copyright owners' right to control the works is limited by Article XX of the Regulations, which excludes their right to control the copyright after signing a contract. The imbalance of rights and obligations between collective management organizations and third parties mainly refers to the imbalance of rights and obligations between organizations and users or agents. As a whole, the Regulations is based on guidelines for the works of management organizations, and there are some problems like the lack of specific provisions or too limited specific provisions, etc.

\subsection{Defects in the Mode of Package Licensing}

Package licensing, that is, bundled licensing, means that after a licensing contract has been signed between a copyright collective management organization and a user, all works under management shall be permitted to be used arbitrarily by the latter in a non-exclusive manner. In the Internet age, users are more likely to pay for a useful piece of work than buying huge databases. Additionally, there are some defects in package licensing, such as the lack of regulations and difficulties in protecting the rights of non-member copyright owners. The lack of regulations is mainly reflected in the unclear type of licensing contracts, the lack of users in the decision-making mechanism of royalty, and limited ways of licensing. In respect of the protection of rights of nonmember copyright owners, collective management organizations also provide collection and distribution of copyright royalties to music copyright owners who are not members of the association. However, the lack of specific provisions makes it difficult to implement, and the lack of corresponding dispute resolution institutions in foreign countries makes it difficult for non-member copyright owners to protect their legitimate rights and interests, so they can only resort to courts after their rights are infringed. 


\subsection{Impact of Digital Technology on Traditional Collective Management System}

Digital technology in the age of intelligence includes cloud computing, big data and block chain, etc. Digital technology has impacted the traditional copyright collective management mode with its advantages of high efficiency and low cost. Some of the advantages of collective management system can be replaced by technological means and are no longer necessary in many trading situations. For example, the cloud computing of digital technology, by taking cloud service as a centralized organization, the high-speed and efficient computing power of cloud service providers allows them to accurately calculate the use of each work and the due income. Therefore, in many cases, copyright owners can bypass collective management organizations and directly obtain the proceeds of the use of the work via cloud service providers, which can be called a functional replacement for the collective management system. Similarly, in the field of big data technology, the use of big data helps copyright owners to accurately calculate the use and infringement of their works, and scientifically protects the interests of copyright owners. The application of block chain technology is helpful for establishing a decentralized copyright trading platform, enabling the matters including the confirmation of copyright registration, the storage of digital assets as well as the copyright traded and protection against copyright infringement to be completed by copyright owners through the trading platform without the help of copyright collective management organizations.

\section{SUGGESTIONS \\ ON THE IMPROVEMENT OF COPYRIGHT COLLECTIVE MANAGEMENT SYSTEM IN THE DIGITAL ERA}

\subsection{Clear the Principle of Interests Balance}

As one of the basic principles of Intellectual Property Law, the principle of interests balance calls for a proper handling of the balance of interests among creators, disseminators and the public. This principle is embodied in two aspects of collective management, one is to avoid damage of the right holder's right to get remuneration caused by the abuse of works, the other is to restrict management organizations' monopoly of rights and achieve good social benefits. The interests of both parties need to be taken into consideration in an all-round way to realize the unification of rights and obligations.

There are three channels to clarify this principle, i.e. legislation, improving management organizations and strengthening supervision mechanism. First of all, the principle of balance of interests should be recognized and embodied in the Regulations, and the above-mentioned characteristics of overall consideration should be embodied in the law revision. Secondly, it is necessary to reduce the restrictions on private copyright agencies in China and endow non-governmental organizations such as network service providers with the role of for-profit collective management organizations to participate in market competitions, thus expanding the choice of users and copyright owners meanwhile protecting their interests. Finally, it is necessary to clarify the strengthening of supervision mechanism, external supervision should be mainly undertaken by administrative organs, the public, professional audit departments and the media, so as to prevent the abuse of rights of collective management organizations; excessive interference of the above supervision should be avoided in internal supervision, so as to optimize the ability of internal governance and achieve a stable dynamic balance between them.

\subsection{Establish a Monopoly-primary and Competition-auxiliary Mode of Management}

Although the monopolistic mode of collective management system is more in line with China's national conditions than the competitive mode, it does not mean that China should absolutely choose the monopolistic mode. There are still many problems caused by the pure legal monopolistic status and strong semi-official administrative background of collective management organizations in our country, such as inflexibility of operation mechanism, unreasonable standards of charges and distribution fees, rigid supervision and administration system, etc. In addition to the regulation of anti-monopoly law, some competition mechanisms should also be properly introduced to form a management mode with monopoly as the principal and competitions as the auxiliary, so as to revise and perfect the copyright collective management system through market competitions.

The introduction of competitive factors is manifested in two aspects: 1) restrictions are opened up on the establishment of collective management organizations, and 2) the control of copyright owners over works is strengthened. Point 1 is to break the uniqueness of collective management organizations, the establishment conditions should be relaxed at the legislative level, which can be changed from the current administrative licensing doctrine to the standard doctrine, allowing copyright owners or market subjects who meet the requirements to set up collective management organizations spontaneously. Point 2 is directed at the exclusive licensing in Article XX of the Regulations, monopolistic exclusive licensing deprives copyright owners of the right to choose and control, which is publicly resisted by copyright owners on a large scale. Under the rapid development of digital technology, nonexclusive licensing is equally important, which can prevent the excessive infringement of collective 
management organizations. Thus, it should go hand in hand with exclusive licensing.

\subsection{Introduce an Extended Collective Management System}

The extended collective management system integrates both voluntary and compulsory, which refers to broadly representative collective management organizations of copyright. Under the authorization of copyright administration departments of the state, indefinitely authorized copyright collective management of non-member copyright owners can be carried out, while non-members also have the right to independently obtain remuneration or prohibit the use of works according to laws. The system is conducive to protecting the interests of copyright owners and users in the digital era and special fields, meanwhile promoting the development of the cultural industry. Extended collective management systems have been applied in countries such as the UK, the five Nordic, Russia and Canada, etc. under the premise that management organizations are widely represented and that agreements can be extended to thirdparty non-member copyright owners with the interests of non-member copyright owners protected.

The system has characteristics of a wide radiation area and an effectively avoidance of infringement, which can effectively protect the interests of non-member copyright owners in the case of large-scale infringement. The large quantity of works and orphan works caused by the digital Internet era can also be effectively protected by the extended management system. In addition to the interests of copyright owners, the extended management system may also protect the interests of users. By signing a user-centric package licensing with users, it is safe to use without the risk of prosecution meanwhile saving their transaction time and cost. Therefore, the introduction of extended management system, combined with digital technology online trading platforms, solves the problem of large-scale infringement and provides symmetrical information for both copyright owners and users, protecting the rights as well as interests of both parties, including non-members.

\section{CONCLUSION}

In order to respond to the challenge of scientific and technological innovations in the digital era under the premise of increasingly frequent trades on copyright, the traditional copyright collective management system of China needs to be transformed to collective management of digital copyright. The principle of interest balance should be implemented, and appropriate competitive factors should be added to the collective management system to construct a new collective management mode. At the same time, the extended collective management system of developed countries should be used for reference, and legislative perfection as well as institutional innovations should be carried out in light of the national conditions, so that the collective management system can play its due role while adapting to the digital era, meanwhile making digital technology effectively used to improve the efficiency of management and expand the scope of its functions, thus the system can be optimized and developed.

\section{REFERENCES}

[1] Xiong Qi. The Source of Judicial Determination of Collective Management of Illegal Copyright. ECUPL Journal.2017(05)

[2] Dai Shuiping. On the Choice of Collective Management Mode of Copyright in China. Journal of Northwestern University.Philosophy and Social Sciences Edition. 2010(01)

[3] Qiu Qianhui. A Study on the Collective Management System of Copyright in China in the Digital Era.P20

[4] Yang Dexing.A Comparative Study on Organizational Systems of Copyright Collective Management-Centered on the Civil Law System.P18

[5] Song Xueping.A Study on the Copyright Licensing System of Musical Works in China's Network Environment.P15-P17

[6] Duan Haifeng. Balanced Allocation of Rights and Obligations-- The Perfect Direction of China's Copyright Collective Management System. Science-Technology Publication 2018(11)

[7] Wu Baiding and $\mathrm{Hu}$ Xiang.Legal Regulation of Package Licensing of Musical Copyright Collective Management Organizations.Price Theory \& Practice 2015(08)

[8] Meng Lei.Copyright Collective Management in the Intelligent Era.Challenges, Reflections and Reconstructions. Publishing Research. 2020(01)

[9] Wang Taiping.Copyright System in a Cloud Computing Environment: Challenges, Opportunities and Future Prospects.Intellectual Property2013(12)

[10] Wang Hui.Analysis of the Reasonableness of Copyright Collective Management Monopoly in the Digital Age. Transmission and Copyright. 2018(05)

[11] Xiong Qi.The Rationality and Legislative Perfection of the Centralized Copyright Licensing Mechanism.Law Science. 2011(08) 
[12] Tong Jiajia.On Musical Copyright Collective Management in China in the Digital Era: from the Perspective of Centralized Permission. P38

[13] Li Yuxiang.A Study on the Collective Management of Extensible Copyright-- Written at the Third Amendment to China's Copyright Law. Law Science. 2013(08) 